\title{
Determination of Optimal Irrigation Scheduling for Maize (Zea Mays) at Assosa District, Benishangul Gumuz Regional State, Ethiopia
}

\author{
Miniebel Fentahun Moges \\ Irrigation and Drainage Research Department, Assosa Agricultural Research Center, Ethiopian Institute of \\ Agricultural Research.
}

\begin{abstract}
Knowing the appropriate time of irrigation and the amount of water applied to the crop is essential to increase yield and water productivity. There was no research activity which was conducted in Assosa district regarding to optimal irrigation scheduling of maize before this study. Therefore, this study was conducted to evaluate the response of maize to irrigation regime( when and how much) and determination of water productivity. Field experiments were conducted in two consecutive years. The experiment had five treatments which were, Soil moisture depletion levels (SMD1 $=60 \%$ of ASMDL, SMD2 $=80 \%$ of ASMDL, SMD3 $=100 \%$ of ASMDL,SDL4= $120 \%$ of ASMDL and SMD5 $=140 \%$ of ASMDL) with RCBD experimental design. Reference evapotranspiration, crop water and net irrigation requirements were calculated. The results were indicated that yield and water productivity were significance at SMD3 or $100 \%$ available soil moisture depletion level of maize variety of BH540. Hence applying irrigation water when the available soil moisture content reaches at critical depletion and $444.2 \mathrm{~mm}$ total net depth of water was contributed.
\end{abstract}

Keywords: Water requirement, Irrigation scheduling, Water productivity, Maize, Assosa

DOI: $10.7176 / \mathrm{JNSR} / 12-3-02$

Publication date: February $28^{\text {th }} 2021$

\section{Introduction}

Irrigation scheduling is the practice of using some method to decide when to start an irrigation system and how much water to apply. No matter what method is used, they all start with knowing when and how much rain has been received on the field and then using some mechanism to decide when to irrigate (Thomas et al., 1999).

The adoption of appropriate irrigation scheduling practices could lead to increased yields and greater profit for farmers, significant water savings, reduced environmental impacts of irrigation and improved sustainability of irrigated agriculture (Smith et al., 1996). Irrigation scheduling is an important irrigation management issues for maximizing production efficiency. It involves determining the proper amount and timing of water applications throughout the growing season.

Determination of the appropriate timing of irrigation usually involves the use of daily ET estimate based on local meteorological data to maintain a daily soil water balance throughout the irrigation season. In Assosa district, Benishangul Gumuz Regional State, production of Maize using in both rainfied and irrigation agriculture is practiced. To obtain high yield and productivity, the amount of water which is applied to the root zone of the crop and the time of application is essential, but the optimal irrigation scheduling of maize was not known before this study. There for, this study was conducted to evaluate the response of Maize to irrigation regime( when and how much) and determination of water productivity.

\section{Materials and Methods}

\subsection{Description of the Study Area}

The study was conducted at Gambashire kebele in Assosa Woreda, Benishangul gumuz Regional state, found in the Upper Blue Nile (Abay) River Basin, Ethiopia. It is located at a distance of about $665 \mathrm{~km}$ to the North West of

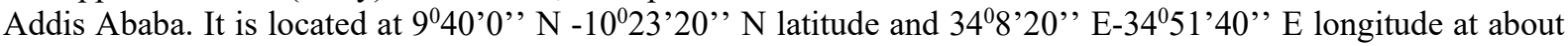
1560 meters above sea level (m.a.s.l).

The agro-climatic zone of the area is hot to warm moist lowland plain with unimodal rainfall distribution pattern. The rainy season starts at the end of April and lasts at the end of October with maximum rainfall in June, July, August and September. The mean annual minimum and maximum temperatures of the area for the same years were 14.63 and $28.61^{\circ} \mathrm{C}$ respectively.

\subsection{Treatments and Experimental Design}

The experiment was done for two consecutive years with test crop of maize ( Variety of BH-540) at the experimental field. The experiment has five treatments which were soil moisture depletion levels. It was laid out in Randomized Complete Block Design (RCBD) with three replications. The experimental field had been a plot size of $20 \mathrm{~m}^{2}$, the space between plots 1.5 meter, and 2 meters between replication. 
Table 1: Treatment setting for field experiment

\begin{tabular}{|l|l|}
\hline Treatments & Description \\
\hline SMD1 & $60 \%$ of ASMDL \\
\hline SMD2 & $80 \%$ of ASMDL \\
\hline SMD3 & ASMDL according to FAO(33) which is $100 \%$ \\
\hline SMD4 & $120 \%$ of ASMDL \\
\hline SMD5 & $140 \%$ of ASMDL \\
\hline
\end{tabular}

Where: ASMDL- available soil moisture depletion level, SMD- soil moisture depletion

\subsection{Data Collection and Analysis}

\subsubsection{Determination of reference evapotranspiration (ETo)}

For the determination of reference evapotranspiration, climatic data such as minimum and maximum temperature and rainfall, relative humidity, sunshine hours, wind speed at two meter height were collected from Assosa Agricultural Research Center meteorological station. Reference evapotranspiration was computed using CROPWAT 8.0 model as a measure of evaporative demand of the atmosphere. It has been estimated with the FAO Penman-Monteith equation (FAO, 2009) using the ETo calculator program using equation 1.

ETo $=\frac{0.408 \Delta(\mathrm{Rn}-\mathrm{G})+\gamma(900 \mathrm{~T}+273) \mathrm{u} 2(\mathrm{es}-\mathrm{ea})}{\Delta+\gamma(1+0.34 \mathrm{u} 2)(3.5)}$

Where:

ETo: reference evapotranspiration ( $\mathrm{mm} /$ day)

$\mathrm{Rn}$ : net radiation at the crop surface $\left(\mathrm{MJ} / \mathrm{m}^{2} /\right.$ day)

$\mathrm{G}$ : soil heat flux density $\left(\mathrm{MJ} / \mathrm{m}^{2} /\right.$ day $)$

T: mean daily air temperature at $2 \mathrm{~m}$ height $\left({ }^{\circ} \mathrm{C}\right)$

es: saturation vapor pressure $(\mathrm{kPa})$

ea: actual vapor pressure $(\mathrm{kPa})$

es - ea: saturation vapor pressure deficit $(\mathrm{kPa})$

$\Delta$ : slope vapor pressure curve $\left(\mathrm{kPa} /{ }^{\circ} \mathrm{C}\right)$

$\gamma$ : psychrometric constant $\left(\mathrm{kPa} /{ }^{\circ} \mathrm{C}\right)$

\subsubsection{Soil Data}

The representative soil samples were collected from the experimental field for the determination of Soil texture, Bulk density (BD), Field capacity (FC) and Permanent wilting point (PWP). Samples were taken by auger up to the maximum root depth of the crop. The particle size distributions in the soil profiles were determined using hydrometric method as stated by Stanley and Bernard (1992). Bulk density of the soil was determined using undisturbed soil samples using $4 \mathrm{~cm}$ height and $4.6 \mathrm{~cm}$ internal diameter and $4 \mathrm{~cm}$ height core sampler. Field capacity and permanent wilting point of the soil were analyzed through pressure plate apparatus in the laboratory with a pressure of $1 / 3$ bar (for field capacity) and 15 bars (for permanent wilting point).

\subsubsection{Crop water requirement}

The crop water requirement was calculated using CROPWAT 8.0 model which is familiar and easy to manipulate. The water requirement of crop was calculated by taking into consideration the growth periods (initial, development, mid season and late season) using CROPWAT 8.0 model. Crop water requirement or ETc can be calculated as:

$\mathrm{ETc}=\mathrm{Kc} \times \mathrm{ETo}$

Where:

ETc: crop evapotranspiration/crop water requirement (mm/day),

Kc: crop coefficient, which is a function of crop type and stage of growth

ETo: reference evapotranspiration ( $\mathrm{mm} /$ day)

\subsubsection{Irrigation water requirement}

The net depth of water required was computed after estimation of total available water. The total available water (TAW) for crop use in the root zone was calculated from field capacity and permanent wilting point using Allen et al.(1998) equation 3.

$\mathrm{TAW}=1000 \Sigma(\theta \mathrm{FC}-\theta \mathrm{PWP}) * \mathrm{BD} * \mathrm{Zr}-$

Where: TAW: volumetric total available water in the root zone $(\mathrm{mm} / \mathrm{m})$

FC: volumetric moisture content at field capacity $\left(\mathrm{m}^{3} / \mathrm{m}^{3}\right)$ and

PWP: volumetric moisture content at permanent wilting point $\left(\mathrm{m}^{3} / \mathrm{m}^{3}\right)$.

BD: bulk density $\left(\mathrm{gm} / \mathrm{cm}^{3}\right)$

$\mathrm{d}_{\text {net }}=\mathrm{TAW} * \mathrm{P}$

Where:

$\mathrm{d}_{\text {net: }}$ net depth of water required $(\mathrm{mm})$

TAW: Total available water

P: water depletion fraction/management allowable depletion (\%) which is the amount of water stored in the soil 
that is readily available to the plant. The value for maize $(\mathrm{P}=0.55)$.

\subsubsection{Irrigation scheduling}

To calculate irrigation interval, first readily available water or net depth of water required was determined from total available water and management allowable depletion as equation 4.

Therefore, the irrigation interval was calculated as:

$\mathrm{I}=\frac{\mathrm{dnet}}{\mathrm{ETc}}$

Where:

I: irrigation interval (days)

\subsubsection{Water productivity}

The water productivity(WP) was calculated as the harvested grain yield of maize per total irrigation water applied. Accordingly: $\mathrm{WP}\left(\frac{\mathrm{kg}}{\mathrm{m} 3}\right)=\frac{\text { Grain yield }\left(\frac{\mathrm{kg}}{\mathrm{ha}}\right)}{\text { Water applied }\left(\frac{\mathrm{m} 3}{\mathrm{ha}}\right)}$

\subsubsection{Statistical analysis}

The collected yield components, yield and water productivity were analyzed using the SAS system for windows 9.0. From the activity yield components, yield and water productivity data were collected and subjected to analysis of variance to identify the difference between the yield and water productivity of different treatments applied. Whenever treatment effects were significant, the means were separated using the least significance (LSD) procedures.

\section{Results and Discussion}

\subsection{Reference evapotranspiration}

The variation of monthly mean value of reference evapotranspiration was indicated in ( Figure 1).The maximum and minimum ETo values were 4.66 and $2.67 \mathrm{~mm} /$ day in January and August respectively. The monthly ETo values for the study period from February to May were 5.03, 4.62, 5.43 and 4.0mm/day during February, March, April and May respectively. The monthly mean ETo value from January to December was $4.01 \mathrm{~mm} / \mathrm{day}$. But the monthly average ETo value for the study period was $4.77 \mathrm{~mm} /$ day. The yearly reference evapotranspiration of the study area was $1442.7 \mathrm{~mm}$, while the total ETo value for the study period was $572.4 \mathrm{~mm}$.

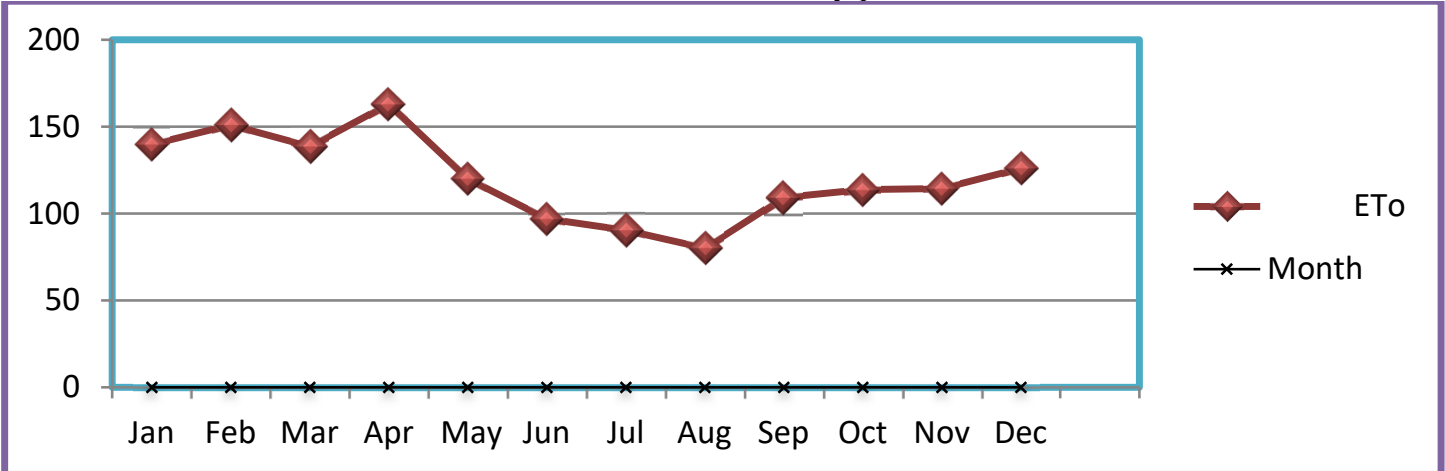

Figure 1: Monthly mean value of ETo

\subsection{Soil data analysis result}

The collected soil data from the experimental field were analyzed and the results were indicated in (Table 2). The textural class of the soil was clay for all soil depth of the experimental field. Bulk density indicates the compactness of the soil and the average bulk density of the soil was $1.1 \mathrm{gm} / \mathrm{cm}^{3}$ which was in the recommended range. The average calculated value of total available water was $156.4 \mathrm{~mm} / \mathrm{m}$ within the acceptable range which was FAO (1998) recommended value for clay soil ranges from $120-200 \mathrm{~mm} / \mathrm{m}$ per depth.

Table 2 : Soil data analysis result of the experimental field

\begin{tabular}{|l|l|l|l|l|l|}
\hline $\begin{array}{l}\text { Soil depth } \\
(\mathbf{c m})\end{array}$ & Textural class & BD $\mathbf{( g m / \mathbf { c m } ^ { 3 }}$ & $\mathbf{F C}(\mathbf{\%})$ & PWP $\mathbf{( \% )}$ & $\begin{array}{l}\text { TAW per depth } \\
(\mathbf{m m})\end{array}$ \\
\hline $0-30$ & clay & 1.01 & 43.43 & 30.21 & 133.52 \\
\hline $30-60$ & clay & 1.05 & 45.52 & 31.12 & 151.20 \\
\hline $60-90$ & clay & 1.17 & 46.60 & 30.80 & 184.86 \\
\hline $90-120$ & clay & 1.19 & 45.44 & 32.33 & 156.00 \\
\hline Average & & 1.10 & 45.23 & 31.10 & 156.40 \\
\hline
\end{tabular}

\subsection{Crop water and irrigation water requirements}

Crop water requirement was calculated using CROPWAT 8.0 model which could be computed by feeding the computed monthly ETo values together with the necessary crop, rainfall and soil data. In calculating the irrigation 
requirement, monthly rainfall data was determined and the effective rain fall was calculated using USDA Soil Conservation Service method according to (FAO, 2009).

Predetermined amount of irrigation water was applied to each plot using standardized 3 inch Parshall flume which was installed at the entrance of the experimental field .The total seasonal crop water requirement was $536.4 \mathrm{~mm}$. The total seasonal net irrigation requirement for $100 \%$ of ASMDL was $444.2 \mathrm{~mm}$. The net irrigation requirement for $60 \%$ of ASMDL was $448.4 \mathrm{~mm}$, for $80 \%$ of ASMDL $446.7 \mathrm{~mm}$, for $120 \%$ of ASMDL $443.8 \mathrm{~mm}$ and for $140 \%$ of ASMDL $442.6 \mathrm{~mm}$.

\subsection{Yield components, Grain yield and Water productivity}

\subsubsection{Yield components and Grain yield}

The results were indicated that plant height and grain yield were highly significance as indicated in (Table 3). The significance was at treatment three. This represents for MAD trial of 100\% available soil moisture depletion level or critical SMDL of Maize variety BH-540. Hence applying irrigation water when the available soil moisture content reaches at critical depletion and $444.2 \mathrm{~mm}$ total net depth of water was contributed for the significance of Maize yield in the study area.

The grain yield of maize was increased as soil moisture depletion levels were increased up to the soil moisture was reached at critical depletion level or critical SMDL as indicated in (Figure 2). After the soil was reached at critical level, the grain yield was decreased which means the amount of water in the soil was above the requirement of the crop or even if the available water in the soil was excess, the crop could not be extract that water (Figure 2). The same concept was reported by Solomon (1983) which was described as available water was increased, yield was increased and when available water was excess, yield was decreased.

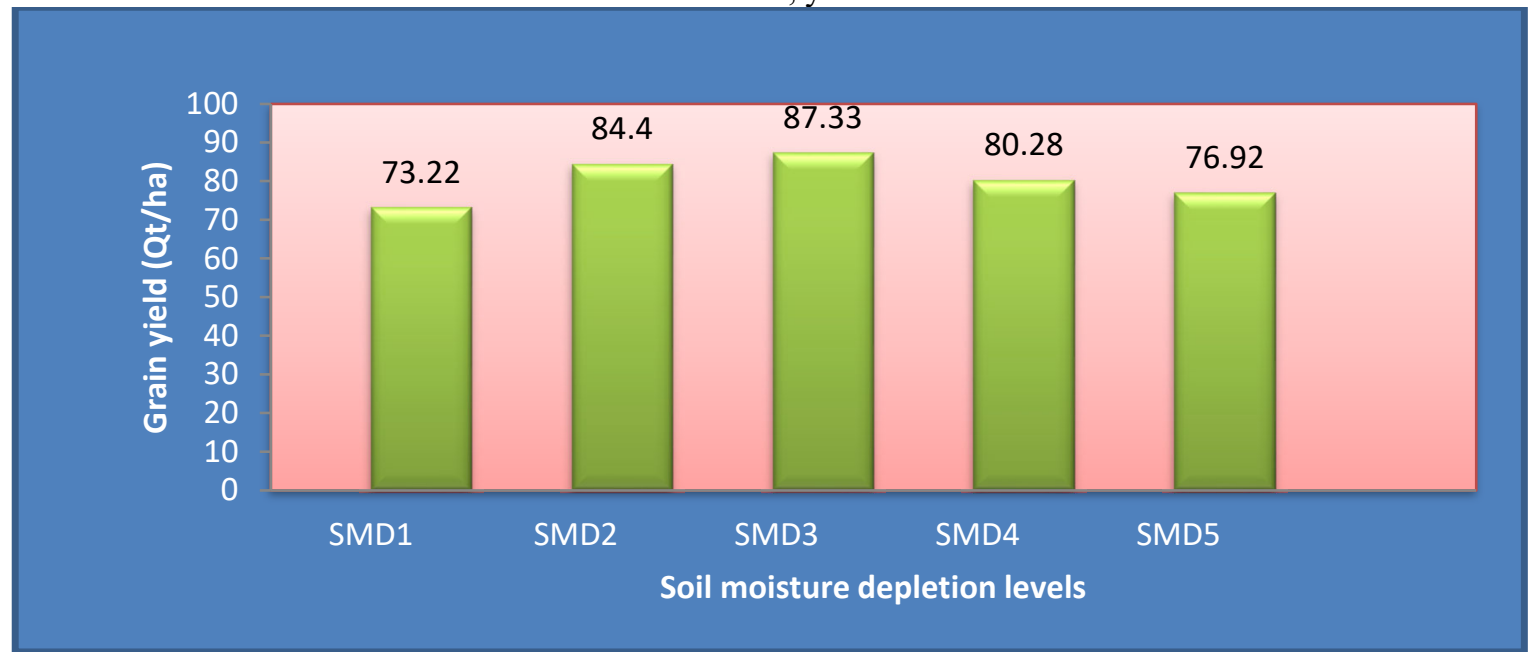

Figure 2. Effect of soil moisture depletion level on grain yield

\subsubsection{Irrigation water productivity}

The highest irrigation water productivity (IWP) was obtained at treatment three ( SMD3 which wa $100 \%$ of ASMDL or at critical depletion) and lowest value was recorded at treatment one (SMD1 which was $60 \%$ of ASMDL) as indicated in (Table 3). Statistically there was no significance difference between critical depletion and $80 \%$ of available soil moisture depletion level and also no significance difference between $120 \%$ and $140 \%$ of available soil moisture depletion levels as shown in (Table 3) .

As the soil moisture depletion levels were increased up to the critical depletion level, the irrigation water productivity results were increased but after the critical depletion level, the water productivity was decreased (experimental result in Figure 3). 


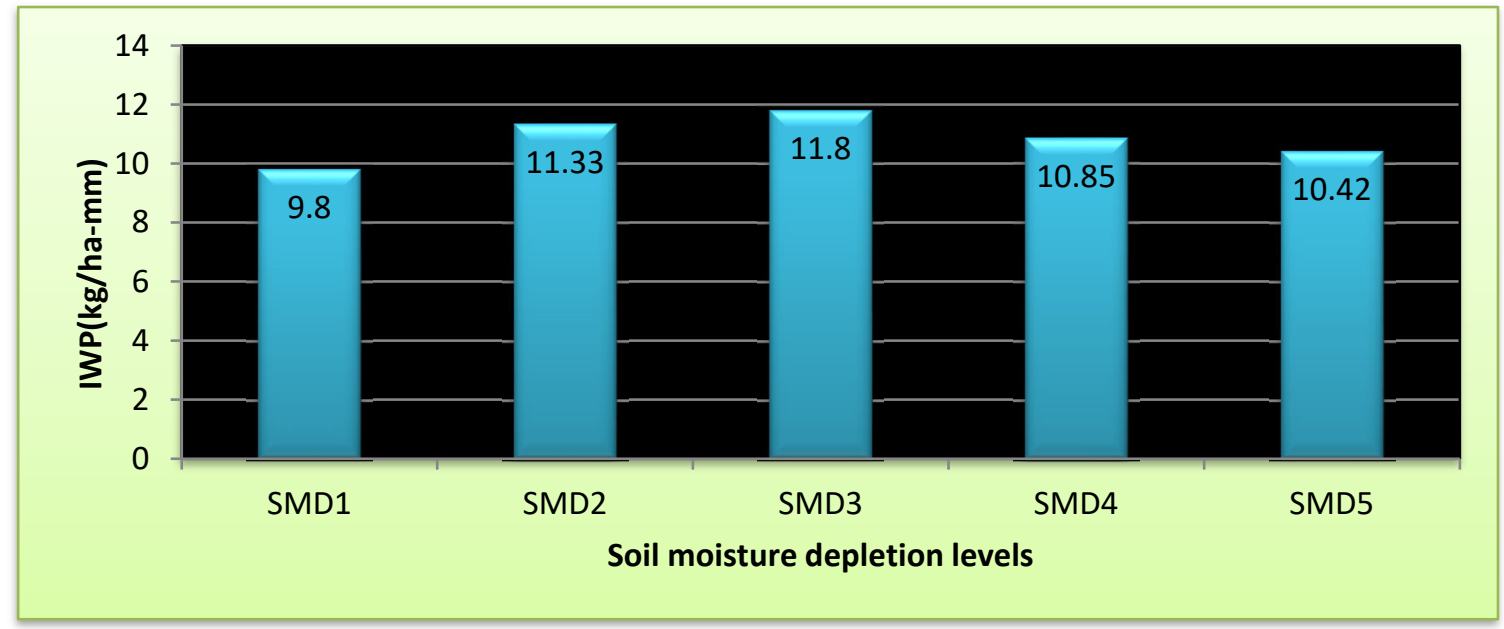

Figure 3. Effect of soil moisture level on irrigation water productivity

Table 3: Analyzed yield components, grain yield and water productivity

\begin{tabular}{|l|l|l|l|l|l|}
\hline TRT & PH $(\mathbf{c m})$ & CL $(\mathbf{c m})$ & EH $(\mathbf{c m})$ & YLD $(\mathbf{Q t} / \mathbf{h a})$ & IWP $(\mathbf{k g} / \mathbf{h a}-\mathbf{m m})$ \\
\hline SMD1 & 183.67 & 14.00 & 102.63 & $73.22^{\mathrm{c}}$ & $9.80^{\text {bc }}$ \\
\hline SMD2 & 226.77 & 17.33 & 109.25 & $84.40^{\mathrm{b}}$ & $11.33^{\mathrm{a}}$ \\
\hline SMD3 & 263.40 & 16.67 & 122.18 & $87.33^{\mathrm{a}}$ & $11.80^{\mathrm{a}}$ \\
\hline SMD4 & 156.33 & 12.00 & 101.20 & $80.28^{\mathrm{bc}}$ & $10.85^{\mathrm{b}}$ \\
\hline SMD5 & 143.33 & 14.00 & 115.45 & $76.92^{\mathrm{c}}$ & $10.42^{\mathrm{b}}$ \\
\hline Sig(P<0.05) & $* *$ & NS & NS & $* * *$ & $*$ \\
\hline CV(\%) & 9.99 & 15.28 & 14.43 & 2.23 & 5.82 \\
\hline
\end{tabular}

NB. PH-plant height, CL-cobe length, EH-ear height, YLD-grain yield, Qt- quintal,1Qt=100kg.

\section{Conclusions}

Maize yield parameters like cobe length and ear height were non-significance due to application of treatments. Consequently, high grain yield and irrigation water productivity were obtained from the $100 \%$ of ASMDL. Therefore, plant height, grain yield and water productivity had a significance effect due to application of treatments. Before and after the critical level, the soil moisture depletion levels had both increasing and decreasing effect on grain yield and water productivity. The net irrigation water requirement of maize could be $444.2 \mathrm{~mm}$ and the irrigation frequency should be once per week for the study area and similar agro ecologies .

\section{Acknowledgements}

First, I thank Almighty God for always being with me in all my endeavors and giving me endurance to complete this study. My special appreciation goes to Ethiopian Institute of Agricultural Research for financial support for the research. I would like to thank Worku Gedefaw and Ayalew Ali for their assistance in field works and data collection during this study.

\section{References}

Allen, R.G., Pereira, L.S., Raes,D. and Smith, M.1998. Crop Evapotranspiration. Guidelines for Computing Crop Water Requirements.FAO Irrigation and Drainage Paper No.56.FAO,Rome.

FAO (Food and Agricultural Organization). CROPWAT Software, Food and Agriculture Organization, Land and Water Division; Available at: 2009.http:/www.fao.org/nr/water/infore s_databases_cropwat.html.

Smith, M., L. S. Pereira, J. Beregena, B.Itier, J. Goussard, R. Ragab, L. Tollefson, P.V. Hoffwegen. 1996. Irrigation Scheduling: From Theory to Practice.FAO Water Report 8, ICID and FAO, Rome .

Solomon, K. 1983. Irrigation uniformity and yield theory. PhD Dissertation, Utah State U., Logan, UT, 271 p.

Stanley, W.C. and Yerima, B. 1992. Improvement of soil services for agricultural development: guidelines for soil sampling and fertility evaluation. Ministry of Natural Resources Development and Environmental Protection, Addis Ababa, Ethiopia.

Thomas, F. S, D. Franzen, J. Lorenzen, A. Lamey, D. Aakre, and D. A. Preston.1999. Growing Irrigated Potatoes, Irrigation Management. North Dakota State University, NDSU Extension service. (http://www.ext.nodak.edu/extpubs/plantsci/rowcrops/ae1040-2.htm) 